\title{
Health surveillance and endocrine disruptors
}

\author{
Vigilância sanitária e desreguladores endócrinos
}

William Waissmann 1,2

\footnotetext{
1 Centro de Estudos da Saúde do Trabalhador e Ecologia Humana, Escola Nacional de Saúde Pública, Fundação Oswaldo Cruz. Rua Leopoldo Bulhões 1480, Rio de Janeiro, $R J$ 21041-210, Brasil. 2 Diretoria de Alimentos e Toxicologia, Agência Nacional de Vigilância Sanitária.

SEPN QD 515, Bloco B, 3o andar, Brasília, DF 70770-520, Brasil. waissmann@netfly.com.br
}

\begin{abstract}
The author discusses the extreme relevance of research on the presence of endocrine disruptors (EDs) in products of interest to health surveillance (HS). Focusing on EDs, the author highlights the urgency of changes already under way in the direction of HS. The shift should be from product and product-registration approaches to the productive process and its realization in consumption, generation of contaminants, and alterations in the health of workers and the overall population. He briefly describes: regulatory gaps for dealing with EDs; difficulty in evaluating risk and suspension of the production and use of products with its characteristics and the need, as exemplified by such products, to enhance the inter-relationship among all stakeholders and to turn HS into a state-of-the-art technological setting, associated with the academic community and accountable to the public. The author reports on measures already taken in relation to EDs, including the establishment of a reference laboratory for analyzing persistent organic pollutants (POPs), interruption of the use of various POPs in Brazil and an initial review of requirements for registering pesticides under the Brazilian National Health Surveillance Agency (ANVISA).
\end{abstract}

Key words Health Policy; Health Surveillance; Endocrine Disruptors

Resumo Descreve-se como da maior relevância, o estudo da presença de "desreguladores endócrinos" (DE) em produtos sob interesse da vigilância sanitária (VS). Demonstra-se, tendo como foco os DE, como são urgentes as mudanças, já iniciadas, de direcionamento da VS. De abordagens centradas nos produtos e em ações cartoriais, há que se verter tanto para a análise do processo produtivo, de sua realização no consumo, na geração de contaminantes e nas alterações da saúde de trabalhadores e da população em geral. São descritas, de modo sucinto: deficiências normativas para o enfrentamento dos DE; a dificuldade de avaliação do risco que representam e a suspensão da produção e uso de produtos com suas características e; a necessidade, que tais produtos exemplificam, de aprimoramento do inter-relacionamento entre todas as partes interessadas e de transformação da VS em ambiente tecnológico de ponta, associada à academia e sob a tutela do interesse público. Relatam-se medidas já tomadas e direcionadas aos DE, como a constituição de um laboratório de referência para análise de poluentes orgânicos persistentes (POPs), a interrupção do uso de vários POPs no Brasil e o início da revisão das exigências para registro de agrotóxicos pela Agência Nacional de Vigilância Sanitária (ANVISA).

Palavras-chave Políticas de Saúde; Vigilância Sanitária; Desreguladores Endócrinos 
Several definitions have been proposed for the substances known in English as endocrine disruptors (EDs). According to some authors, EDs are limited to chemical agents capable of producing alterations in the hormone system by binding to specific receptors (like androgen, estrogen, progesterone, and aromatic hydrocarbon receptors) or by interfering with the expression of the receptor-hormone bond, antagonizing or stimulating a given endocrine pathway. Other authors contend that the term encompasses all substances leading to alterations in the endocrine system by any type of action (including direct glandular chemical injury or by stimulating a hormone metabolism) (Gaido et al., 1998; Kavlock et al., 1996).

For the purposes of Health Surveillance, interference causing disorders in the endocrine system is cause for major concern, whatever the substances involved. The concern is reflected by a term with a broader scope in the Portuguese language, not easily translated as the English term "disruptors", i.e., interferentes endócrinos or "endocrine interferents", based on the belief that such substances can be more than "deregulators" or "disruptors", terms commonly used as neologisms or that basically connote a chronic state. The term "interferent" allows one to typify but not restrict a substance's action on the endocrine system, maintaining the sense of chronic effects without ruling out the risk of acute or even emergency toxicity with such a substance.

There is a long list of substances with the potential to interfere in the endocrine system. Along with their metabolites, they include: dibromoacetic acid; acrylamide; arochlor; atrazine; benzo(a)anthracene; benzo(a)pyrene; bisphenol A; 1-bromopropane; lead; cadmium chloride; chlozolinate; compounds with zinc, manganese, or mercury; DDT; 1,2 dibromo-3chloropropane; dieldrin; endosulfan; phthalates; hexachlorocyclohexane; butylated hydroxytoluene; butyl hydroxyanisole; iprodione; kepone; methyl-tert-butyl-ether (MTBE); methoxychlor; PCBs; PCDDs; PCDFs; pentylphenol; procimidone; octylphenol; nonylphenol; toxaphene; triacyl phosphates; triazole; tricresyl phosphates; vinclozolin; and various other compounds (Cooper et al., 2000; Hodges et al., 2000; Ichihara et al., 2000; Latendresse et al., 1994; Mathews \& Zacharewski, 2000; Smeets et al., 1999a, 1999b; Waalkes et al., 1999; Williams et al., 2000).

Many of these substances persist in the environment even when they have no longer been produced for years in Brazil, amplifying in the food chain, as in the case of certain organochlo- rine compounds. Many "endocrine interferents" are pesticides, like atrazine, chlozolinate, iprodione, and vinclozolin. Some are by-products of the combustion or production of certain other inputs, like the PCDDs and PCDFs, and contaminate food products, which is possible with (amongst others) butylated hydroxytoluene and butyl hydroxyanisole, used to delay oxidative processes and extend the shelf life of food products. Bisphenol A, phthalates, MTBE, tricresyl phosphates, and triacyl phosphates are used in plastics, lubricants, rubber products, and synthetic materials, many of which are used to manufacture toys or used routinely in dentistry, vials, medical equipment, and even syringes. Ultimately all of them may be present in substances, products, or manufacturing processes pertaining to health surveillance.

For a long time the view taken by academic circles in Public Health (and not without a basis in reality) was that Brazilian health surveillance was a sort of bureaucratic law enforcement system that uncritically certified products for a wide variety of health fields. Health surveillance was seen as an area of government where health-related products had to be registered, thereby gaining Ministry of Health certification for the market. The system worked for various products, like medicines and pharmaceuticals, foodstuffs, cosmetics, and home cleaning products.

Criticism of the bureaucratic approach was focused on these functions. In general, until the 1980s, the process of reviewing applications for certification was ineffective or even non-existent as an object of public interest. An application to register a product followed a bureaucratic route, with few experts prepared to conduct an in-depth review, and applications were invariably approved. Certification was more the result of a proper bureaucratic ritual than a real health need, i.e., nothing more than a "notary public office", with no real critical capability in terms of health. When a critical review was conducted, it concentrated more on the product's intrinsic characteristics, especially its potential for acute toxicity or microbial contamination. The notion of process, the modes and means of production, and potential or real aggression to the environment and workers were largely overlooked.

In addition, inspection measures at the local level targeted retail food sales, restaurants, bars, and similar commercial establishments. Their case-resolution capacity was limited, and the health inspection process was more of a law enforcement act, with ineffective require- 
ments lacking either a health nexus or an educational focus. In many cases such inspection lacked either an ethical commitment or health knowledge, but had authoritarianism and ignorance to spare.

Health surveillance is in fact a field that includes product certification, but the responsibilities have changed since the old days. Current reality must move beyond the red tape and spot inspections of the past. Product registration should not merely involve a stamp of sanitary inspection issued by official agencies that evaluate little or nothing of the product's healthfulness. And the frame of reference must be shifted from the old focus on "the product" to the manufacturing process. Health and the environment must be seen as the result of a production process. The premise is that any manufacturing process involves factors that are transformed. Raw materials, energy sources, machinery, and workers enter, and products, residues, transformed machines and instruments, and modified people come out. Just as the view of production interrelates the product, consumption, and factors involved in production, based on market strategies and the "cost-benefit" relationship in each stage of production, health logic should focus on each of these phases, realizing that each stage of these strategies and moments can involve a health risk to be minimized. And in addition to the effects and residues that are produced and disseminated, often without regard for borders, these stages should include not only a normative commitment, but a partnership between the state, the academic community, consumers, workers, producers, and commerce, monitored by the public interest.

As the scope of health surveillance is modified, its methods change. It is relevant to know how things are produced, with what quality, and at what environmental cost for workers and consumers. This simultaneously involves turning the health surveillance system and in particular the National Health Surveillance Agency (ANVISA) into a state-of-the-art technological platform. Such a change requires analyzing the adequacy of new technologies and products in an environment where the interests of society and the international community are heard.

The case of endocrine interferents illustrates the need to understand the many difficulties still involved in the system in order to implement relevant changes and fulfill its health role.

One initial challenge is the Brazilian health surveillance legislation itself. It is urgent to un- derstand its weaknesses and adjust it to current needs. Prime examples are Ruling 14 of January 24, 1992 (Brasil, 1992b) and Ruling 03 of January 16, 1992 (Brasil, 1992a). Ruling 14 sets the criteria for preliminary toxicological evaluation of pesticides targeted for research and experimentation, governs research and experimentation with these products, and generically classifies the principles it accepts as tests for evaluating toxicity. However, it fails to specify the adverse hormonal effects to be assessed, while dictating the tests and assays to be conducted according to the specifications published by one of the following agencies: World Health Organization (WHO), International Program on Chemical Safety (IPCS/WHO), International Agency for Research on Cancer (IARC/ WHO), Pan American Center for Human Ecology and Health (ECO/PAHO), United Nations Food and Agriculture Organization (FAO), International Registry of Potentially Toxic Chemicals of the United Nations Environment Program (IRPTC/UNEP), Organization for Economic Cooperation and Development of the European Economic Community (OECD/EEC), and the United States Environmental Protection Agency (EPA).

Ruling 03 specifies the "guidelines and requirements pertaining to authorization of registration, renewal of registration, and extension of use of agricultural pesticides and related chemicals". According to the Ruling in relation to requirements for toxicological assessment " $a$ pesticide is considered to have hormonal action impeding its registration when there is no level without an adverse effect in experiments with animals or humans, hormonal alteration occurs at all test doses, and the effect is not reversible by interrupting administration of or exposure to the chemical substance".

The fact that these rulings fail to specify the adverse hormonal effects or analytical indicators cannot be solved by relying on international standards and regulations. Inversely, the broad range of reference agencies listed above fosters a false sense of protection. In addition, the lack of consensus among these organizations as to the signs of adverse hormonal effects can lead to acceptance of different criteria for one and the same effect. Since Brazilian legislation lacks incentives for developing research and Brazilian standards for EDs, it reinforces this gap and fails to encourage recognition of their toxicity by the Brazilian population. In addition, the Ruling apparently aims to protect the right to register a product, at least insofar as its potential endocrine toxicity is involved. There is a clear gap between merely 
preventing the registration of products with irreversible hormonal effect at all the tested doses and the high risk that a large number of compounds pose to the endocrine system. There is an urgent need for a national policy directly targeting EDs and greater standardization, without which there can be no reduction in the risks they pose.

However, all these normative changes can only be linked together by the above-mentioned re-focusing of health surveillance on the production process and by in-depth incorporation of toxicology, articulated with the context and methods employed by public health in the system's daily practice. This is the reason for being of the General Toxicology Management Section (GGT) under the Food and Toxicology Division of the ANVISA. The GGT should orient its work towards this in-depth refocusing. Among its various roles, the GGT: coordinates the Brazilian National System for Toxicological and Pharmacological Information (SINITOX); implements new models to organize and manage training, surveillance, and treatment in toxicology; issues technical toxicological reports serving as the basis for approving or denying registration of pesticides by the Ministry of Agriculture; organizes the Brazilian network of laboratories for residue analysis; is building a laboratory for analysis of Persistent Organic Pollutants (POPs), especially dioxins (PCDDs), and furans (PCDFs); reevaluates certification of pesticides and redefines toxicological criteria for their acceptance; participates in Brazilian and international forums for the standardization of toxic substances, such as those on Prior Informed Consent (PIC), POPs, the International Forum on Chemical Substances, CODEX ALIMENTARIUS, and Toxic and Biological Weapons; and participates in the Brazilian National Technical Commission on Biosafety and in groups and committees focusing on the environment within the Ministry of Health. All these activities relate to the set of compounds with potential hormonal action, among those that are more or less directly related to endocrine disruptors or interferents.

The goal of the GGT is a horizontal approach to the field of toxicology, acting at all necessary stages, regardless of the product or process being investigated, involving evaluation of the toxicological risk posed by products and their components, analyzing and proposing new forms of control and prior or post-registration toxicological analysis of products. However, most of these measures are still in the initial phase. The priorities have been to deal with pesticides and to coordinate the SINITOX, even with guidelines that are still somewhat modest as compared to the GGT's full goals, while demanding great effort by the staff involved in the process, who are facing the kinds of antagonisms that are routine in demanding and implementing substantive changes in Brazilian health surveillance.

However, the Brazilian health surveillance system should not seek to solve its needs exclusively from within, through its own staff. Based on the demands of Brazilian reality, the ANVISA should increasingly encourage the pursuit of technical and political solutions that meet the requirements of community participation and the identification of existing expertise in the country.

The broad range of issues illustrates the interest of the Brazilian health surveillance system, and specifically the ANVISA, in the approach to the specific case of EDs. Several relevant issues are at stake for the population's health. For example, it is crucial to know how and where to intervene in the production chain. Is it always feasible to suspend the production and use of hazardous products? A significant portion of products in widespread use have the potential to interfere with the endocrine system. This fact is of the utmost gravity, but also requires caution. DDT is an important example. Despite international pressure to suspend its use, one cannot force African countries to stand by passively as their people catch malaria and die. Possible substitutes require high additional annual costs. A possible replacement for DDT in some cases might be pyrethroids like deltametrin, with an estimated additional cost of $U \$ 350$ million. In other cases, like South Africa, the switch to pyrethroids was disastrous, with a 20 -fold increase in malaria cases. In such cases there is a need for a "non-pyrethroid" alternative like the organophosphates, which in some situations can be highly toxic and demand an additional expenditure of at least U\$950 million a year (Attaran, 2000; Attaran \& Maharaj, 2000), a cost which is unfeasible for the African reality and which the developed world is unwilling to cover in its entirety (UNEP, 2001).

Especially for products for which there are no known feasible substitutes on the market, one must determine the real effects on humans and animals that recommend immediate interruption of their use. Such facts are often difficult to elucidate. For example, focusing on EDs as one of its environmental priorities, the United States government has supported research to identify the compounds, concentrations, and forms of consumption that entail real risk. 
A reliable assessment is thus a sophisticated process, requiring attempts to interrelate experimental, clinical, and epidemiological data with manufacturing possibilities and different social realities (Kavlock, 1999; Macilwain, 1998). Even then, numerous difficulties have arisen, beginning with the search for a clear understanding of how such substances act. A single chemical agent can bind to different receptors, producing multiple forms of endocrine interference, with distinct effects and bonds, depending on the species studied. An example is bisphenol A in certain species (Sohoni \& Sumpter, 1998), which displays median antiestrogen activity but intense anti-androgen activity, and with the octyls and nonylphenols, with estrogenic and progestagenic action (Laws et al., 2000). In some cases the same receptor can even mediate different effects, as in the case of receptors for aromatic compounds under the effect of dioxins, like 2,3,7,8 TCDD (Gray et al., 1999). Neither is it simple to assume that one can extrapolate or interrelate epidemiological findings and data obtained from animal and human studies. The question arises as to whether the variations in sperm quality (apparently specific to some regions) and the large number of cases of endometriosis and polycystic ovaries are due at least partially to anthropogenic EDs. As for the natural phytoestrogens, what is the relevance of their relationship to compounds produced by humans? Various previously tested end-points have proven insufficient to evaluate hormonal effects in vitro and in vivo, even as new ones have emerged (Kavlock, 1999). What methodologies should be used to define such effects for the purpose of authorizing or prohibiting the use of a given substance?

However, in order for us to relate social needs, standards, and incentives for research in the field, such facts demand a dynamism that is still missing in the Brazilian reality. Even with great progress in the field of toxicology, especially for pesticides (an important range of EDs), there is still a long way to go. There is no way to quickly solve the problem of an entire stock of PCBs present in thousands of electric transformers. A significant number of potentially hazardous pesticides are still in use. Dioxins and furans persist as a major environmental problem, as in the case of contaminated cow's milk in Germany, the origin of which was citrus pellet cattle feed imported from Brazil whose acidity was corrected using lime contaminated with those compounds (Brooks et al., 1999; Carvalhaes et al., 1999; Malish et al., 1999).
Some products with feasible substitutes and for which international norms facilitate action are already prohibited in Brazil. Such is the case for POPs, which are prohibited mainly because of their risk of bioaccumulation, amplification, and carcinogenicity (at least part of which is hormone-dependent). In Brazil, besides DDT being excluded from use in public health campaigns, the country has agreed to the control (and whenever possible the complete prohibition) of the following chemicals listed as POPs by the UNEP: aldrin, chlordane, dieldrin, DDT, endrin, hexachlorobenzene, mirex, toxaphene, PCBs, dioxins, and furans. Heptachlor, one of the POPs listed by UNEP, is still authorized for use in Brazil as a wood preservative, but negotiations have already started between ANVISA, the Ministry of the Environment, and the Ministry of Agriculture and Supply to interrupt its use (UNEP, 2001).

Despite the progress outlined above, the issue of EDs is still new to the health surveillance field in Brazil. The Food and Toxicology Division has launched a number of relevant measures on these substances, as listed above. However, the work thus far is still insufficient, and the goal is to provide a specific approach and appropriate coverage to the problem. Much remains to be done, and it is no longer possible to postpone inclusion of the issue as a public policy environmental priority. The next step should be to establish a working group on the issue with the participation of consultants from the academic community and whose roles will include: developing a systematic approach to EDs in collaboration with other government agencies and organized civil society, thereby avoiding, as in the case of 1-bromopropane, correcting one problem (reducing the effect on the ozone layer) while producing another (endocrine interference) (Ichihara et al., 2000); identify research priorities on endocrine disruptors as the targets for support from ANVISA; create a literature base on the issue, using periodic reevaluations to generate texts that portray the "state of the art", the "state of techniques", and the "state of practices" in relation to EDs; establish a lecture program on endocrine disruptors with the State and municipal health surveillance departments; propose standardization in conjunction with the Ministries of Environment and of Agriculture and Supply, aimed at adapting to current knowledge the requirements for registering, handling, and disposing of chemical substances; maintain a link with sister agencies in other countries in order to exchange information, updates, and standards; serve as a consulting 
body to the Food and Toxicology Division in relation to EDs.

To interfere in the endocrine system means interrupting normal development pathways, generating deformities and diseases with potential repercussions on future generations of humans and the biota in general. The ANVISA and the national health surveillance system must tackle the issue with the necessary caution and without false promises, but trusting in the capacity of Brazilian public health personnel to deal with the problem.

\section{References}

ATTARAN, A., 2000. International Donor Support for Phasing Out POPs: Recommendations for Poor Countries at INC-5, 2000. Working Paper 57. Cambridge: Center for International Development at Harvard University.

ATTARAN, A. \& MAHARAJ, R., 2000. Doctoring malaria badly: The global campaign to ban DDT. $B M J$, 321:1403-1404.

BRASIL, 1992a. Portaria no 3, de 16 de Janeiro de 1992. Brasília: Secretaria Nacional de Vigilância Sanitária, Ministério da Saúde.

BRASIL, 1992b. Portaria no 14, de 24 de Janeiro de 1992. Brasília: Secretaria Nacional de Vigilância Sanitária, Ministério da Saúde.

BROOKS, P.; CARVALHAES, G. \& KRAUSS, T., 1999. Chlorinated components in lime used in production of contaminated citrus pulp pellets from Brazil. Organohalogen Compounds, 41:19-22.

CARVALHAES, G.; BROOKS, P. \& KRAUSS, T., 1999. Lime as the source of PCDD/F contamination in citrus pulp pellets from Brazil. Organohalogen Compounds, 41:137-140.

COOPER, R. L.; STOKER, T. E.; TYREY, L.; GOLDMAN J. M. \& McELROY, W. K., 2000. Atrazine disrupts the hypothalamic control of pituitary-ovarian function. Toxicological Sciences, 53:297-307.

GAIDO, K.; DOHME, L.; WANG, F.; CHEN, I.; BLANKVOORT, B.; RAMAMOORTHY, K. \& SAFE, S., 1998. Comparative estrogen activity of wine extracts and organochlorine pesticide residues in food. Environmental Health Perspectives, 106 (Sup. 6):1347-1351.

GRAY Jr., L. E.; WOLF, C.; LAMBRIGHT, C.; MANN, P.; PRICE, M.; COOPER, R. L. \& OSTBY, J., 1999. Administration of potentially antiandrogen pesticides (procymidone, linuron, iprodione, chlozolinate, p,p'-DDE, and ketoconazole) and toxic substances (dibutyl and diethyl hexyl phthalate, PCB169, and ethane dimethane sulphonate) during sexual differentiation produces diverse profiles of reproductive malformations in the male rat. Toxicology and Industrial Health, 15:94-118. 
HODGES, L. C.; BERGENSON, J. S.; HUNTER, D. S. \& WALKER, C. L., 2000. Estrogenic effects of organochlorine pesticides on uterine leiomyoma cells "in vitro". Toxicological Sciences, 54:355-364.

ICHIHARA, G.; XIAOZHONG, Y.; JUNZONG, K.; NOBUYUKI, A.; KUMAZAWA, T.; IWAI, H.; SHIBATA, E.; YAMADA, T.; WANG, H.; XIE, Z.; MAEDA, K.-H.; TSUKAMURA, H. \& TAKEUCHI, Y., 2000. Reproductive toxicity of 1-bromopropane, a newly introduced alternative to ozone layer depleting solvents, in male rats. Toxicological Sciences, 54:416-423.

KAVLOCK, R. J., 1999. Overview of endocrine disruptor research activity in the United States. Chemosphere, 39:1227-1236.

KAVLOCK, R. J.; DASTON, G. P.; DE ROSA, C.; FLUNER-CRISP, P.; KAATARI, S.; LUCIER, G.; LUSTER, M.; MAC, M. J.; MACZKA, C.; MILLER, R.; MOORE, J.; ROLLAND, R.; SCOTT, G.; SHEEHAN, M.; SINK, T. \& TILSON, H. A., 1996. Research needs for the risk assessment of health and environmental effects of endocrine disruptors: A report of the US sponsored workshop. Environmental Health Perspectives, 104(Sup. 4):715-740.

LATENDRESSE, J. R.; BROOKS, C. L. \& CAPEN, C. C., 1994. Pathologic effects of butylated triphenyl phosphate-based hydraulic fluid and tricresyl phosphate on the adrenal gland, ovary, and testes in the Fisher-344 rat. Toxicologic Pathology, 22: 341-352.

LAWS, S. C.; CAREY, S. A.; FERRELL, J. M.; BODMAN, G. J., \& COOPER, R. L., 2000. Estrogenic activity of octylphenol, nonylphenol, bisphenol A and methoxyclor in rats. Toxicological Sciences, 54: 154-167.

MACILWAIN, C., 1998. US panel split on endocrine disruptors. Nature, 395:828.

MALISCH, R.; BERGER, B. \& VERSTRAETE, F., 1999. Lime as source for PCDD/F-contamination of Brazilian citrus pulp pellets (CPPS). Organohalogen Compounds, 41:51-53.
MATTHEWS, J. \& ZACHAREWSKI, T., 2000. Differential binding affinities of PCBs, HO-PCBs, and Aroclors with recombinant human, Rainbow trout (Onchorhynkiss mykiss), and Green Anole (Anolis carolinensis) estrogen receptors, using a semihigh throughput competitive binding assay. Toxicological Sciences, 53:326-339.

SMEETS, J. S.; HOLSTEIJN, I.; GIESY, J. P. \& VAN DEN BERG, M., 1999a. The anti-estrogenicity of Ah receptor agonists in carp (Cyprinus carpio) hepatocytes. Toxicological Sciences, 52:178-188.

SMEETS, J. S.; HOLSTEIJN, I.; GIESY, J. P.; SEINEN, W. \& VAN DEN BERG, M., 1999b. Estrogenic potencies of several environmental pollutants, as determined by vitellogenin induction in a carp hepatocyte assay. Toxicological Sciences, 50:206-213.

SOHONI, P. \& SUMPTER, J. P., 1998. Several environmental oestrogens are also anti-androgens. Journal of Endocrinology, 158:327-339.

UNEP (United Nations Environmental Program), 2001. Report of the Intergovernmental Negotiation Committee for an International Legally Binding Instrument for Implementing International Action on Certain Persistent Organic Pollutants on the Work of its Fifth Section. Johannesburg: UNEP.

WAALKES, M. P.; ANVER, M. \& DIWAN, B. A., 1999. Carcinogenic effects of cadmium in the noble (NBL/Cr) rat: Induction of pituitary, testicular, and injection site tumors and intra-epithelial proliferative lesions of the dorso-lateral prostate. Toxicological Sciences, 52:154-161.

WILLIAMS, T. C.; CATTLEY, R. C. \& BORGHOFF, S. J., 2000. Alterations in endocrine responses in male Sprague-Dawley rats following oral administration of methyl-tert-butyl-ether. Toxicological Sciences, 54:168-176.

Submitted on 5 March 2001

Final version resubmitted on 2 August 2001

Approved on 9 October 2001 